\title{
Transfer of Maleic Hydrazide into Mainstream Cigarette Smoke*
}

\author{
by \\ W. Wood, G.L. Dooly, and S.C. Moldoveanu \\ Brown \& Williamson Tobacco Corp., 2600 Weaver Rd., Macon GA, 31217, USA.
}

\section{SUMMARY}

This report presents the results of a study regarding the transfer of maleic hydrazide $(\mathrm{MH})$ into mainstream cigarette smoke. Cigarettes with different levels of $\mathrm{MH}$ were used in this study. This included cigarettes with MH preexistent in the tobacco due to the agronomical practice, and with spiked $\mathrm{MH}$. Because the MH can be present in tobacco as bound and free forms, both levels of $\mathrm{MH}$ were measured in the tobacco section. The cigarette designs covered a range of possibilities, including Plain, Filter King Size (KS), Lights 100 's, Ultra Lights, etc. The results showed that the amount of $\mathrm{MH}$ in smoke, on the one hand, is a function of the total particulate matter (TPM) of the cigarette, and higher TPM levels lead to more $\mathrm{MH}$ in smoke. On the other hand, the transferred level of $\mathrm{MH}$ depends on the total amount of $\mathrm{MH}$ (both bound and free) in the tobacco. The relative \% transfer is higher for lower $\mathrm{MH}$ levels than for higher $\mathrm{MH}$ levels in tobacco. When normalized by TPM, the transfer as an average is about $0.24 \%$ per mg of TPM from the amount of $\mathrm{MH}$ in $1 \mathrm{~g}$ of tobacco, and as high as $0.46 \%$ per $\mathrm{mg}$ of TPM from the amount of $\mathrm{MH}$ in $1 \mathrm{~g}$ tobacco for a nonfilter low $\mathrm{MH}$ level cigarette. The resulting $\mathrm{MH}$ transfer for a nonfilter cigarette with low tobacco $\mathrm{MH}$ is therefore about $8.3 \%$ from the total $\mathrm{MH}$ in the cigarette. For filter full flavor (FF) cigarettes with high tobacco levels of $\mathrm{MH}$, the transfer is about $5.8 \%$. This relative transfer rate appears to be lower from higher MH levels in tobacco. [Beitr. Tabakforsch. Int. 20 (2003) 325-330]

\section{ZUSAMMENFASSUNG}

Dieser Bericht fasst die Ergebnisse einer Studie über den Transfer von Maleinsäurehydrazid (MH) in den Hauptstromrauch von Zigaretten zusammen. In dieser Studie wurden verschiedene Zigaretten mit unterschiedlichen $\mathrm{MH}-$ Konzentrationen untersucht, darunter sowohl Zigaretten, bei denen MH bereits im Tabak aufgrund agronomischer Praktiken vorhanden war, als auch Zigaretten, die mit $\mathrm{MH}$ dotiert wurden. Da MH im Tabak sowohl in gebundener als auch in freier Form vorliegen kann, wurden die Konzentrationen beider MH-Fraktionen im Tabak gemessen. Eine breite Palette von Zigarettenarten wurde untersucht, einschließlich Zigaretten ohne Filter, Filter King Size (KS), Lights 100's, Ultra Lights, etc. Die Ergebnisse zeigen, dass die Menge des MH im Zigarettenrauch einerseits als Funktion der im Rauch enthaltenen Gesamtpartikelmasse (TPM) dargestellt werden kann; je höher die TPM Menge, umso mehr MH liegt im Zigarettenrauch vor. Die Gesamtmenge des transferierten MH hängt anderseits von der Gesamtmenge an MH (sowohl gebunden als auch frei) im Tabak ab. Der relative prozentuale Transfer ist bei niedrigen MH-Konzentrationen höher als bei hohen $\mathrm{MH}-$ Konzentrationen. Bezogen auf TPM beträgt der Transfer durchschnittlich ca. 0,24\% der in $1 \mathrm{~g}$ Tabak enthaltenen MH-Menge pro mg TPM; bei filterlosen Zigaretten mit niedrigen MH-Konzentrationen kann der Transfer auf bis zu 0,46\% der in $1 \mathrm{~g}$ Tabak enthaltenen MH-Menge pro mg TPM ansteigen. Dies bedeutet, dass bei einer filterlosen Zigarette mit niedriger MH-Konzentration ca. 8,3\% der Gesamtmenge des in der Zigarette enthaltenen MH transferiert werden. Bei "Full Flavour" (FF)

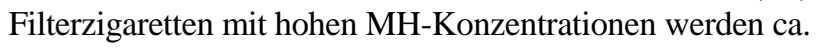
$5,8 \%$ transferiert. Diese relative Transferrate scheint bei höheren MH-Konzentrationen im Tabak niedriger zu sein. [Beitr. Tabakforsch. Int. 20 (2003) 325-330]

\section{RESUME}

Ce rapport présente les résultats d'une étude sur le transfert de l' hydrazide maléique $(\mathrm{MH})$ dans la fumée du courant principal des cigarettes. Dans cette étude, des cigarettes avec différentes teneurs en MH ont été utilisées. Certaines de ces cigarettes comportaient du MH préexistant dans le tabac par pratique agronomique, alors que chez d'autres le $\mathrm{MH}$ a été apporté. En raison du fait que le $\mathrm{MH}$ peut apparaître dans le tabac sous forme libre ou conjugé, les deux teneurs de $\mathrm{MH}$ ont été mesurées dans la colonne de tabac. L'étude inclus des cigarettes de diverses conceptions dont des cigarettes sans filtre, des cigarettes extra longues (KS) avec filtre, des cigarettes légères 100 's, des cigarettes ultra-légères, etc. Les 
résultats de l'étude ont révélé que la quantité de $\mathrm{MH}$ présente dans la fumée est, d'une part, fonction de la matière particulaire totale (MPT) de la cigarette et que plus les teneurs en MPT sont élevées plus il y a de MH dans la fumée. D'autre part, la teneur de $\mathrm{MH}$ transférée dépend de la quantité totale de MH (conjuguée et libre). Le pourcentage relatif de transfert est plus élevé pour des teneurs basses en MH que pour des teneurs élevées. Lorsqu' on le rapporte à la MPT, le transfert de MH s'élève en moyenne à environ $0,24 \%$ de la quantité de $\mathrm{MH}$ présente dans $1 \mathrm{~g}$ de tabac par mg de MPT, et peut atteindre $0,46 \%$ de la quantité de MH présente dans $1 \mathrm{~g}$ de tabac par mg de MPT pour une cigarette sans filtre à faible teneur en $\mathrm{MH}$. Le transfert de $\mathrm{MH}$ d'une cigarette sans filtre à faible teneur en $\mathrm{MH}$ est donc environ $8,3 \%$ du $\mathrm{MH}$ total dans la cigarette. Pour les cigarettes à filtre plein arôme (FF) ayant des teneurs élevées en $\mathrm{MH}$, le transfert s'élève à environ 5,8\%. Le pourcentage relatif de transfert semble être faible pour des teneurs plus élevées en $\mathrm{MH}$ dans le tabac. [Beitr. Tabakforsch. Int. 20 (2003) 325-330]

\section{INTRODUCTION}

Maleic hydrazide (MH) is a synthetic plant growth regulator widely used in tobacco farming as a suckering control agent. $\mathrm{MH}$ is typically applied on the upper part of tobacco plants after topping. In time, the $\mathrm{MH}$ becomes distributed through the whole plant where it is present both as unmodified $\mathrm{MH}$ and $\mathrm{MH}$ metabolites. One of the typical $\mathrm{MH}$ metabolites is a $\beta$-D-glucoside (1). The total level of $\mathrm{MH}$ in the processed leaf and in the tobacco from cigarettes ranges between a few $\mu \mathrm{g} / \mathrm{cig}$ up to about $100 \mu \mathrm{g} / \mathrm{cig}$. Pyrolysis at $600{ }^{\circ} \mathrm{C}$ of pure $\mathrm{MH}$, performed in the present study, indicates that at elevated temperatures some $\mathrm{MH}$ is transferred unmodified into the pyrolysate. The transfer of $\mathrm{MH}$ from tobacco to cigarette smoke is therefore likely. Several previous studies report $\mathrm{MH}$ transfer into smoke. LIU and HOFFMANN were the first to report that the transfer rate of $\mathrm{MH}$ depends on the concentration of MH in tobacco (2). The transfer rate indicated by LIU and HOFFMANN (2) ranged from $4 \%$ to $10 \%$. HAEBERER and CHORTYK (3) found a transfer rate of only $0.2 \%$. A report by the U.S. Department of Agriculture (4) indicated a transfer of 2-3\% of MH to mainstream smoke, while CHOPRA et al. (5), showed values between $2.5 \%$ and $2.8 \%$. Additionally, Liu $e t$ al. (6) indicated that $\mathrm{MH}$ is present in smoke even if the tobacco was not treated with $\mathrm{MH}$.

The variability in the reported results on $\mathrm{MH}$ transfer is complicated by the fact that the analysis of $\mathrm{MH}$ in plant material must capture both free and bound MH. To accomplish the analysis of total $\mathrm{MH}$, a hydrolysis of bound $\mathrm{MH}$ must be performed. Typically this is done with aqueous $\mathrm{HCl}$ and heating (7-12). This hydrolysis requires rather strong conditions, and concentrations of $\mathrm{HCl}$ between 2 and $12 \mathrm{~N}$ are used in different methods. The ISO 4876 method and the official method of the Association of the Official Analytical Chemists apply an acidic digestion followed by hydrolytic reduction of the free $\mathrm{MH}$ to hydrazine with $\mathrm{Zn}$ in aqueous $\mathrm{NaOH}$. Hydrazine is steam distilled into a $p$-dimethylaminobenzaldehyde solution and the resulting reaction product analyzed spectrophotometrically (13-15).

The disagreement between the reported results of $\mathrm{MH}$ trans- fer indicated a need for further studies. The present work was done to clarify the reasons for differences among previously published results. It started with the pyrolysis of pure $\mathrm{MH}$ to establish the capability of $\mathrm{MH}$ to transfer unmodified into pyrolysates. Then, measurements of $\mathrm{MH}$ on tobacco and smoke were performed. The procedure for $\mathrm{MH}$ analysis in tobacco was taken from the literature (11) and an original procedure based on derivatization with $\mathrm{N}, \mathrm{O}$-bis(trimethylsilyl)trifluoroacetamide (BSTFA) for the analysis of MH in smoke condensate was applied. Several cigarette brands with tobacco having various levels of MH were evaluated and the results are compared to those reported in the literature.

\section{EXPERIMENTAL}

The materials used for the experimental part of this study are as follows: MH from Chem Services Inc. (West Chester, PA, USA), BSTFA from Regis Technologies Inc. (Morton Grove, IL, USA), dimethylformamide (DMF) from Burdick and Jackson (Muskegon, MI, USA), tert-butylhydroquinone and docosanoic acid from Aldrich (Saint Louis, MO, USA). The pyrolysis of pure MH was done using two different systems, an on-line pyrolysis-gas chromatography-mass spectrometry (Py-GC-MS) and an off-line system. The on-line system consisted of a CDS AS2500 pyrolysis autosampler, connected to a CDS 2000 pyroprobe, and an Agilent 6890-5973 GC-MS system. The sample was pyrolyzed in the pyroprobe at $600{ }^{\circ} \mathrm{C}$ for 10 $\mathrm{sec}$, and the pyrolysates were transferred to the GC-MS system for analysis. The GC was equipped with a $60 \mathrm{~m}$ long, $0.25 \mathrm{~mm}$ i.d. and $0.5 \mu \mathrm{m}$ film thickness DB-Wax capillary column. The oven was programmed at an initial temperature of $40{ }^{\circ} \mathrm{C}$ for $2 \mathrm{~min}$, a heating rate of $2{ }^{\circ} \mathrm{C} / \mathrm{min}$ to $240{ }^{\circ} \mathrm{C}$, and a final time of $20 \mathrm{~min}$.

For the off-line system a Pyroprobe 100 was used. The pyrolysis was performed in similar conditions as those used for on-line analysis and the collection and derivatization of pyrolysate was done by a procedure reported previously (16). In this procedure, the pyrolysate is collected in a 1-m length of $0.53-\mathrm{mm}$ i.d. untreated fused silica tube. Approximately $0.25 \mathrm{~m}$ from the exit end of the silica tube, a loop of the tube is immersed in ice water. After pyrolysis, the tube is flushed with helium for $1 \mathrm{~min}$. The tube is then removed from the ice water bath and the ends inserted into two sealed GC autosampler vials. One of the vials contains a mixture of $80 \mu \mathrm{L}$ BSTFA and $40 \mu \mathrm{L}$ DMF. Using gas pressure, the liquid was passed through the collection tube several times to wash the pyrolysate. After washing, the solution is heated for $30 \mathrm{~min}$ at $76^{\circ} \mathrm{C}$ and analyzed using a GC-MS system. The GC is equipped with a $20 \mathrm{~m}$ long, $0.18 \mathrm{~mm}$ i.d. and $0.25 \mu \mathrm{m}$ film thickness DB-5 capillary column. The oven is programmed at an initial temperature of $50{ }^{\circ} \mathrm{C}$ for $2 \mathrm{~min}$, a heating rate of $5{ }^{\circ} \mathrm{C} / \mathrm{min}$ to $200{ }^{\circ} \mathrm{C}$, and $8{ }^{\circ} \mathrm{C} / \mathrm{min}$ to $300^{\circ} \mathrm{C}$ and a final time of $12 \mathrm{~min}$. The injection is done at $275^{\circ} \mathrm{C}$. $\mathrm{MH}$ is present in several tautomeric forms and in the presence of BSTFA, the enol form reacts as shown in Figure 1.

The mass spectrum of silylated MH or 3,6-bis[(trimethylsilyl)oxy]-pyridazine is similar to that of silylated 2,5-dihydroxypyrazine and is shown in Figure 2. The quantitation was done using the area of the MH peak in the total ion chromatogram. 


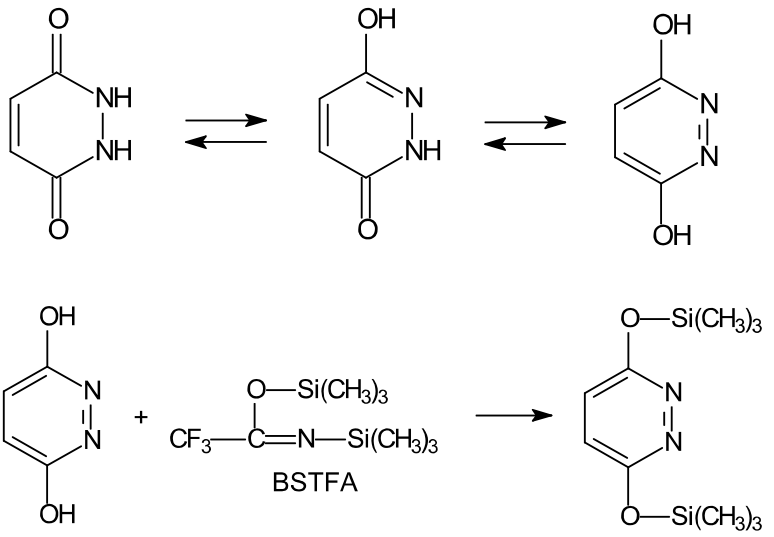

Figure 1. Tautomeric forms of maleic hydrazide and the reaction with $\mathrm{N}, \mathrm{O}$-bis(trimethylsilyl)trifluoroacetamide

The analysis of $\mathrm{MH}$ in smoke is done after 5 cigarettes are smoked onto a small Cambridge pad, under (Federal Trade Commission (FTC) conditions using a Borgwaldt RM20/CS smoking machine. The smoke pad is then extracted with $10 \mathrm{~mL}$ methanol on a mechanical shaker for $20 \mathrm{~min}$. The solution is transferred into a test tube, heated at $65^{\circ} \mathrm{C}$ under a $\mathrm{N}_{2}$ stream, and the methanol is evaporated to dryness. The residue is dissolved in $1 \mathrm{~mL}$ DMF containing $400 \mu \mathrm{g} / \mathrm{mL}$ tert-butylhydroquinone $+200 \mu \mathrm{g} / \mathrm{mL}$ docosanoic acid, followed by the addition of $0.5 \mathrm{~mL}$ BSTFA. The solution is heated at $76{ }^{\circ} \mathrm{C}$ for $30 \mathrm{~min}$ and analyzed by GC-MS using conditions similar to those used to analyze the pyrolysate. Some cigarettes were spiked with different levels of $\mathrm{MH}$. For this purpose, a 10 or $20 \mu \mathrm{L}$ solution of $\mathrm{MH}$ was injected, and the spiked cigarettes were equilibrated for $10 \mathrm{~d}$ before smoking. The concentration of $\mathrm{MH}$ in methanol was prepared to yield the desired amount of $\mathrm{MH}$ in the cigarette. No further verification of the achieved $\mathrm{MH}$ levels on the cigarettes was done.

The quantitation of $\mathrm{MH}$ in cigarette smoke is done following a calibration curve made using standards of pure $\mathrm{MH}$. The standard solutions used to make the calibration curve are prepared starting with a stock solution of $1 \mathrm{mg} / \mathrm{mL} \mathrm{MH}$, $400 \mu \mathrm{g} / \mathrm{mL}$ tert-butylhydroquinone (internal standard no.1)

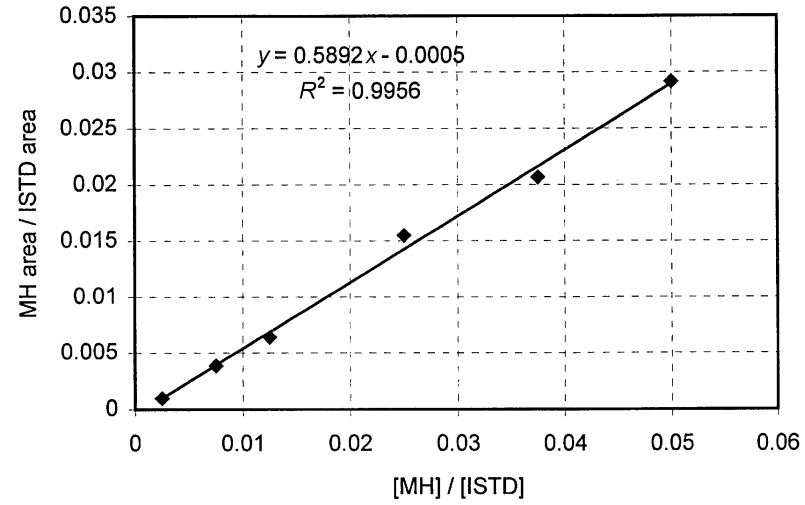

Figure 3. Calibration curve for the determination of $\mathrm{MH}$ in smoke

and $200 \mu \mathrm{g} / \mathrm{mL}$ docosanoic acid (internal standard no. 2) in $\mathrm{N}, \mathrm{N}$-dimethylformamide (DMF). This solution is diluted to $200 \mu \mathrm{g} / \mathrm{mL}$ MH with DMF containing the same concentration of internal standards, and various volumes from this solution were further diluted to generate each point. Three replicates of each concentration were prepared to generate the calibration curve. The calibration curve for $\mathrm{MH}$ in smoke is shown in Figure 3.

The analysis of $\mathrm{MH}$ in tobacco is done following two different procedures. The first procedure is developed to analyze only the free tobacco $\mathrm{MH}$. For this purpose, $250 \mathrm{mg}$ of ground tobacco is extracted with $1 \mathrm{~mL}$ methanol in a $2 \mathrm{~mL}$ capped vial by heating at $76{ }^{\circ} \mathrm{C}$ for $30 \mathrm{~min}$. The vial is then cooled to room temperature and the liquid material from the vial is separated by centrifugation and filtration. The liquid is transferred into a vial, heated at $65{ }^{\circ} \mathrm{C}$ under a $\mathrm{N}_{2}$ stream, and the methanol is evaporated to dryness. The residue is analyzed like the smoke extract. For quantitation, tobacco free of MH was spiked with various levels of $\mathrm{MH}$ and processed as previously described. The quantitation is done using the calibration curve shown in Figure 4.

The repeatability of the procedure has been tested near the lower limit of measurement and the results are shown in Table 1. Taking as detection limit the value of $3 \mathrm{SD}$, the

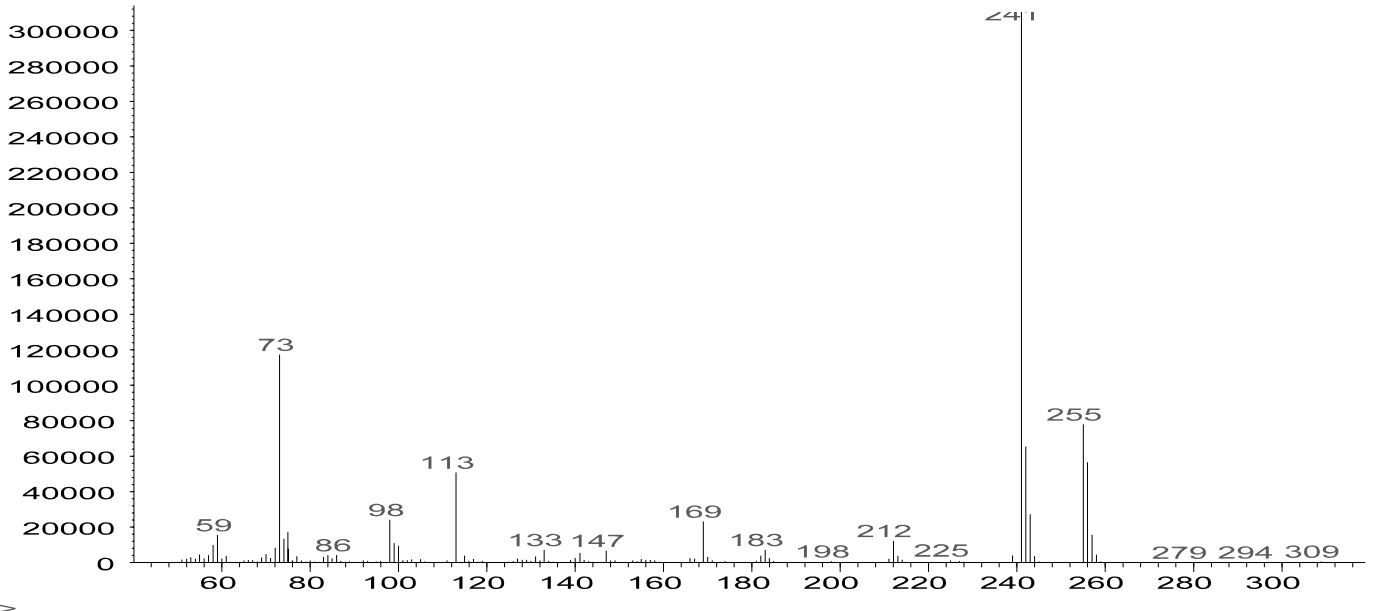

Figure 2. Mass spectrum of 3,6-bis[(trimethylsilyl)oxy]-pyridazine (MH-2 TMS) 


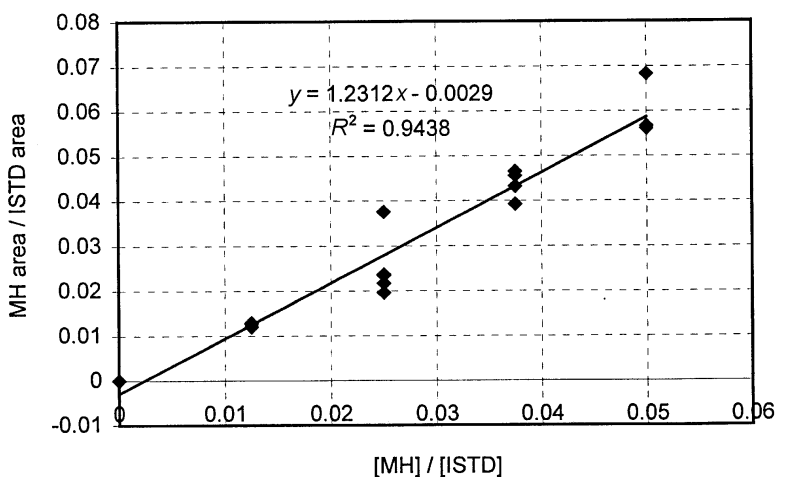

Figure 4. Calibration curve for the determination of $\mathrm{MH}$ in tobacco.
Table 1. Study of the repeatability of the MH determination in the tobacco of a commercial filter KS cigarette with low MH level

\begin{tabular}{lc}
\hline$\mu g \mathrm{MH} / \mathrm{g}$ tobacco & $\left(x_{i}-x_{\text {mean }}\right)^{2}$ \\
\hline 9.85 & 0.013 \\
9.24 & 0.239 \\
10.59 & 0.728 \\
9.07 & 0.446 \\
10.14 & 0.168 \\
9.51 & 0.049 \\
Mean $=9.73$ & $\mathrm{SD}^{\mathrm{a}}=0.57$ \\
\hline
\end{tabular}

${ }^{\mathrm{a}} \mathrm{SD}=$ standard deviation .

Table 2. The level of total MH, free MH, and MH in mainstream smoke on a per-cigarette basis for various non-spiked and MHspiked cigarette brands

\begin{tabular}{|c|c|c|c|c|c|}
\hline Cigarette brands & $\begin{array}{c}\text { Total } \mathrm{MH} \\
(\mu \mathrm{g} / \mathrm{cig})\end{array}$ & $\begin{array}{c}\text { Free } \mathrm{MH} \\
(\mu \mathrm{g} / \mathrm{cig})\end{array}$ & $\begin{array}{c}\text { MH in smoke } \\
(\mu \mathrm{g} / \mathrm{cig})\end{array}$ & $\begin{array}{c}\text { TPM } \\
\text { (mg/cig) }\end{array}$ & $\begin{array}{c}\mathrm{g} \text { Tobacco } \\
\text { (in } 1 \mathrm{cig} \text { ) }\end{array}$ \\
\hline \multicolumn{6}{|c|}{ Non-spiked samples } \\
\hline Experimental KS A & 0.0 & $2.5^{\mathrm{a}}$ & 0.30 & 21 & 0.649 \\
\hline Plain end (no filter) KS & 12 & 5.8 & 1.00 & 18 & 0.960 \\
\hline Full Flavor KS & 8.4 & 3.7 & 0.87 & 17 & 0.697 \\
\hline Ultra Lights 100's & 9.4 & 5.9 & 0.24 & 5.8 & 0.784 \\
\hline Lights 100's & 9.5 & 6.5 & 0.63 & 11 & 0.794 \\
\hline Menthol Mild KS & 26 & 9.8 & 1.30 & 13 & 0.650 \\
\hline Menthol 100's & 33 & 12 & 2.30 & 22 & 0.819 \\
\hline Experimental KS B & 79 & 26 & 3.30 & 19 & 0.789 \\
\hline 1 mg TPM cig 100's & 18 & 5.3 & 0.07 & 1 & 0.679 \\
\hline \multicolumn{6}{|c|}{ MH-spiked samples } \\
\hline Menthol 100's + $20 \mu \mathrm{g} /$ cig MH & 58 & 35.8 & 2.30 & 19 & 0.819 \\
\hline Experimental KS B + $20 \mu \mathrm{g} /$ cig MH & 103 & 50.7 & 3.90 & 19 & 0.789 \\
\hline Experimental $\mathrm{KS} \mathrm{A}+6.5 \mu \mathrm{g} / \mathrm{cig} \mathrm{MH}$ & 6.5 & 6.0 & 0.29 & 20 & 0.649 \\
\hline Experimental $\mathrm{KS} \mathrm{A}+13 \mu \mathrm{g} / \mathrm{cig} \mathrm{MH}$ & 13 & 11.5 & 0.74 & 19 & 0.649 \\
\hline Experimental $\mathrm{KS} \mathrm{A}+26 \mu \mathrm{g} /$ cig $\mathrm{MH}$ & 26 & 24.0 & 1.30 & 19 & 0.649 \\
\hline
\end{tabular}

${ }^{a}$ Note: The result for total $\mathrm{MH}$ in the experimental KS A cigarette is $0.0 \mu \mathrm{g} / \mathrm{cig}$, while the result for free $\mathrm{MH}$ is $2.5 \mu \mathrm{g} / \mathrm{cig}$. The bound and free $\mathrm{MH}$ were measured by different analytical techniques, and this discrepancy is within experimental error of the two methods.

results shown in Table 1 indicate a detection limit of about $1.5 \mu \mathrm{g} / \mathrm{g}$ of tobacco.

The analysis of total $\mathrm{MH}$ was performed by an external laboratory. The method used for this analysis is similar to that described in a literature report (11). For the analysis, $5 \mathrm{~g}$ of tobacco was extracted by boiling under reflux in $100 \mathrm{~mL}$ of $4 \mathrm{~N} \mathrm{HCl}$ for $40 \mathrm{~min}$. The extract is allowed to cool and is filtered. A few $\mathrm{mL}$ of solution are passed through a C-18 SPE column and a $3 \mathrm{~mL}$ sample is collected. A $10 \mu \mathrm{L}$ aliquot is injected in a high performance liquid chromatography (HPLC) system equipped with a C-8 column. The elution is done using isocratic conditions with $0.3 \% w / v \mathrm{H}_{3} \mathrm{PO}_{4}$ in water $(\mathrm{pH} \approx 2)$ at $0.5 \mathrm{~mL} / \mathrm{min}$. The optical density is measured at $320 \mathrm{~nm}$.

\section{RESULTS AND DISCUSSION}

The result of $\mathrm{MH}$ pyrolysis indicates that a significant amount of MH passes unchanged into the pyrolysate. The relatively high thermal stability of $\mathrm{MH}$ and its volatility allowed for part of the $\mathrm{MH}$ to volatilize and leave the pyrolyzer before decomposition. The decomposed part of $\mathrm{MH}$ consisted of some ammonia, $\mathrm{CO}_{2}$, butanoic acid, aminobutyric acid, traces of acetonitrile, acrylonitrile, $1 \mathrm{H}$ pyrrole-2,5-dione, etc. This result indicates that besides $\mathrm{MH}$ itself, no specific toxicological concerns are raised by the presence of $\mathrm{MH}$ in cigarettes. To obtain quantitative information on the transfer of MH in smoke, it was necessary to determine the levels of $\mathrm{MH}$ in both the tobacco and the smoke of each type of cigarette.

Cigarettes with different levels of MH were used in this study. This included cigarettes with agronomically added $\mathrm{MH}$ in the tobacco, and with spiked MH. Because the MH can be present as bound and free forms, both levels of $\mathrm{MH}$ were measured in the tobacco section. The cigarette designs covered a range of possibilities, including Plain, Filter KingSize (KS), Lights 100's, Ultra Lights, etc. cigarettes. The level of total $\mathrm{MH}$, free $\mathrm{MH}$, and $\mathrm{MH}$ in smoke were analyzed as previously described. The results are given in Table 2 and are all expressed on a per-cigarette basis. The data from Table 2 were further processed by normalizing the 
Table 3. The level of MH/TPM in mainstream smoke and the MH levels in $1 \mathrm{~g}$ tobacco for various non-spiked and MH-spiked cigarette brands

\begin{tabular}{|c|c|c|c|}
\hline Cigarette brands & $\begin{array}{c}\mu \mathrm{g} \mathrm{MH} \text { in smoke/ } \\
\text { mg TPM }\end{array}$ & $\begin{array}{c}\text { Total } \mu \mathrm{g} \mathrm{MH} / \\
\mathrm{g} \text { tobacco }\end{array}$ & $\begin{array}{c}\text { Free } \mu \mathrm{g} \mathrm{MH} / \\
\mathrm{g} \text { tobacco }\end{array}$ \\
\hline \multicolumn{4}{|c|}{ Non-spiked samples } \\
\hline Experimental KS A & 0.014 & 0 & $3.9^{\mathrm{a}}$ \\
\hline Plain end (no filter) KS & 0.058 & 12 & 6.0 \\
\hline Full Flavor KS & 0.052 & 12 & 5.3 \\
\hline Ultra Lights 100 's & 0.042 & 12 & 7.6 \\
\hline Lights 100's & 0.056 & 12 & 8.2 \\
\hline Menthol Mild KS & 0.100 & 40 & 15.0 \\
\hline Menthol 100's & 0.104 & 40 & 14.0 \\
\hline Experimental KS B & 0.172 & 100 & 33.0 \\
\hline 1 mg TPM cig 100's & 0.066 & 26 & 7.9 \\
\hline \multicolumn{4}{|c|}{ MH-spiked samples } \\
\hline Menthol 100's + $20 \mu \mathrm{g} / \mathrm{cig} \mathrm{MH}$ & 0.121 & 71 & 44.0 \\
\hline Experimental KS B + $20 \mu \mathrm{g} / \mathrm{cig} \mathrm{MH}$ & 0.200 & 131 & 64.0 \\
\hline Experimental KS A $+6.5 \mu \mathrm{g} / \mathrm{cig} \mathrm{MH}$ & 0.015 & 10 & 9.2 \\
\hline Experimental KS A + $13 \mu \mathrm{g} / \mathrm{cig} \mathrm{MH}$ & 0.039 & 20 & 18.0 \\
\hline Experimental KS A + $26 \mu \mathrm{g} / \mathrm{cig} \mathrm{MH}$ & 0.069 & 40 & 37.0 \\
\hline
\end{tabular}

aNote: The result for total $\mathrm{MH}$ in the tobacco for the experimental $\mathrm{KS} \mathrm{A}$ cigarette is $0.0 \mu \mathrm{g} / \mathrm{g}$ while the result for free $\mathrm{MH}$ is $3.9 \mu \mathrm{g} / \mathrm{g}$. The bound and free $\mathrm{MH}$ were measured by different analytical techniques, and this discrepancy is within experimental error of the two methods.

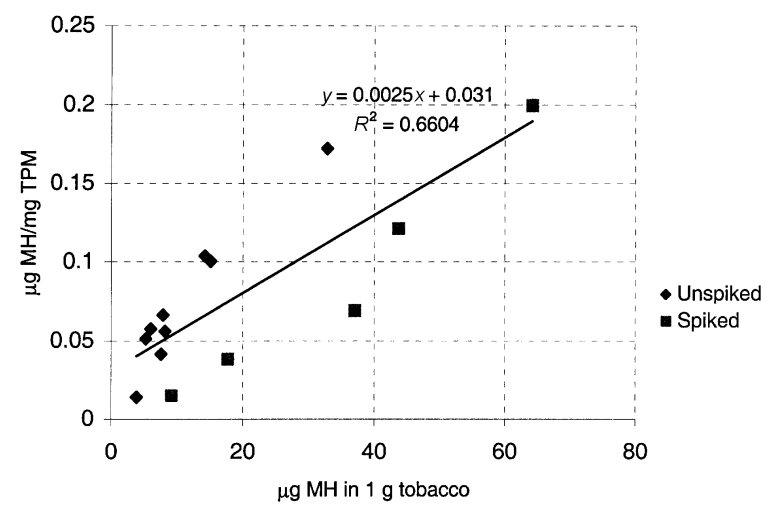

Figure 5. Plot showing the variation of normalized MH by TPM in smoke as a function of free $\mathrm{MH}$ in $1 \mathrm{~g}$ tobacco

amount of MH in smoke by the amount of total particulate matter (TPM), and by calculating the total and free levels of MH for $1 \mathrm{~g}$ of tobacco. The results are summarized in Table 3 and were used to produce Figures 5, 6, and 7 .

The first finding in this study can be obtained by inspecting the graphs that show the variation of MH in smoke normalized by TPM levels as a function of the amount of MH per $1 \mathrm{~g}$ tobacco. The graph for free MH in tobacco is shown in Figure 5 and the graph for total $\mathrm{MH}$ in tobacco is shown in Figure 6 . As seen by comparing the two dependencies, a much better correlation is obtained for the dependence of $\mathrm{MH}$ in smoke as a function of total $\mathrm{MH}$ rather than free $\mathrm{MH}$, in $1 \mathrm{~g}$ tobacco $\left(R^{2}\right.$ coefficient 0.93 for total $\mathrm{MH}$ vs. $R^{2}$ coefficient 0.66 for free $\mathrm{MH}$ ). This result indicates that the MH in smoke depends on the total MH present in tobacco, and not only on the free $\mathrm{MH}$.

Further evaluations were done to establish the rate of transfer of MH to smoke, considering the total amount of MH in tobacco. Attempting a non-linear correlation between the amount of $\mathrm{MH}$ in tobacco and the amount of

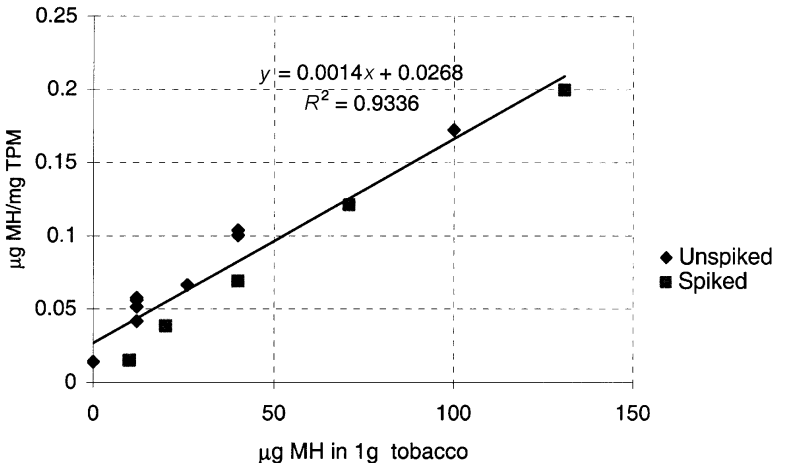

Figure 6. Plot showing the variation of normalized MH by TPM in smoke as a function of total MH in $1 \mathrm{~g}$ tobacco

MH normalized by TPM in smoke, it can be seen that the relative transfer rate decreases as the level of $\mathrm{MH}$ increases. This is shown in Figure 7 where the slope of the curve decreases at higher MH levels in tobacco. The increase in the transfer rate of $\mathrm{MH}$ at the lower levels can be explained by the hypothesis that $\mathrm{MH}$ is formed in smoke even when it is absent in tobacco, as reported by LiU et al. (6). This formation appears to be quite unlikely considering the chemical structure of $\mathrm{MH}$. However, the analysis of tobacco for the presence of total MH is relatively difficult. Part of the bound MH in tobacco may remain unhydrolyzed during analysis and therefore undetected. This undetected $\mathrm{MH}$ in the tobacco may be the cause of the apparent formation of $\mathrm{MH}$ in the smoke of cigarettes with zero values for the analytical MH level. If this is the case, the $\mathrm{MH}$ formed from the bound undetected $\mathrm{MH}$ has a greater impact on the transfer rate calculation for low MH-containing tobaccos than from high $\mathrm{MH}$-containing tobaccos. This hypothesis was not verified experimentally in the present study. 


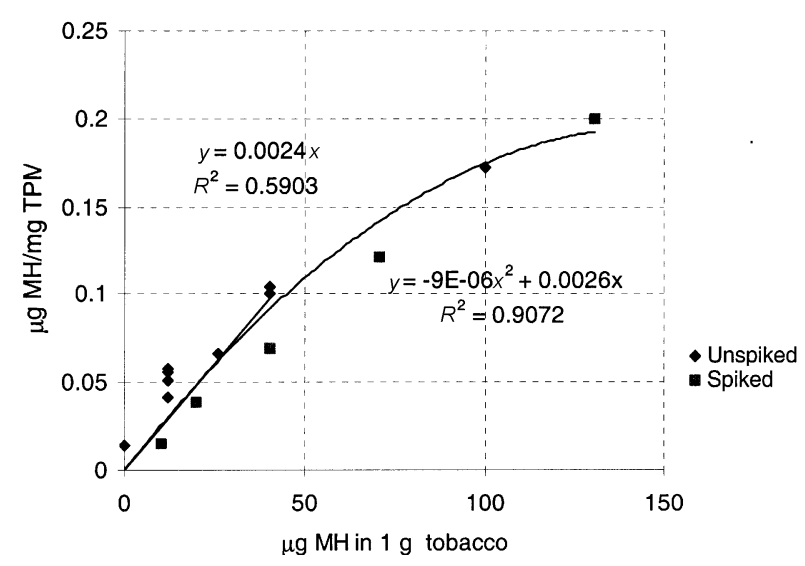

Figure 7. The estimation of transfer rate of $\mathrm{MH} / \mathrm{mg}$ TPM for various levels of total $\mathrm{MH}$ in $1 \mathrm{~g}$ tobacco

Limiting the level of $\mathrm{MH}$ in tobacco to about $40 \mu \mathrm{g} / \mathrm{g}$ tobacco, the transfer rate is about $0.24 \% / \mathrm{mg}$ TPM, but it can range as high as $0.46 \% / \mathrm{mg}$ TPM for a nonfilter cigarette low in $\mathrm{MH}$. Lower transfer rates are seen for higher levels of total $\mathrm{MH}$ in cigarette, the values being around $0.14 \% / \mathrm{mg}$ TPM.

As seen from these results, the amount of $\mathrm{MH}$ in smoke is a function of cigarette TPM, and higher TPM levels lead to more $\mathrm{MH}$ in smoke. By reporting the results as $\mathrm{MH} / \mathrm{mg}$ TPM, it was attempted to eliminate factors related to cigarette construction (tobacco weight, cigarette paper porosity, ventilation, filter efficiency). The results expressed as $\mathrm{MH} / \mathrm{mg}$ TPM for $1 \mathrm{~g}$ tobacco can be easily expressed as transfer rate for a particular cigarette. For a nonfilter low $\mathrm{MH}$ level cigarette the transfer is about $8.3 \%$ from the total $\mathrm{MH}$ in the cigarette. Lower transfers are seen for other cigarettes.

\section{CONCLUSIONS}

This report presents the results of $\mathrm{MH}$ measurements in tobacco and in cigarette mainstream smoke. The amount of $\mathrm{MH}$ in smoke is a function of cigarette TPM, and higher TPM levels lead to more MH in smoke. The transferred level of $\mathrm{MH}$ depends on total amount of $\mathrm{MH}$ (both bound and free) and not only on the free $\mathrm{MH}$ level in tobacco. The relative transfer is higher for lower tobacco MH levels than for higher MH levels. Regardless of the cigarette construction, the transfer is about $0.24 \%$ per $\mathrm{mg}$ TPM as an average. However, for a nonfilter cigarette low in $\mathrm{MH}$, as much as $0.46 \% / \mathrm{mg}$ TPM is transferred from $1 \mathrm{~g}$ tobacco. This is equivalent to $8.3 \%$ from the total $\mathrm{MH}$ in the cigarette. The findings are in agreement with those of LIU and HOFFMANN (2).

\section{REFERENCES}

1. Meyer, S.A., T.J. Sheets and H. Seltmann: Maleic hydrazide residues in tobacco and their toxicological implications; Rev. Environ. Contam. Toxicol. 98 (1987) 43.

2. Liu, Y.Y. and D. Hoffmann: Quantitative chromatographic determination of maleic hydrazide in cigarette smoke; Anal. Chem. 45 (1973) 2270-2273.

3. Haeberer, A.F. and O.T. Chortyk: Gas-liquid chromatographic determination of maleic hydrazide in tobacco and tobacco smoke; J. Assoc. Offic. Agric. Chem. 62 (1979) 171-175.

4. US Department of Agriculture: The biologic and economic assessment of maleic hydrazide; Tech. Bull. 1634 (1980) 1-106.

5. Chopra, N.M., S.N. Hawks Jr. and T.H. Zuniga: On the fate of maleic hydrazide in tobacco smoke; J. Agric. Food. Chem. 30 (1982) 672-676.

6. Liu, Y.Y., I. Schmeltz and D. Hoffmann: Chemical study on tobacco smoke. Quantitative analysis of hydrazine in tobacco and cigarette smoke; Anal. Chem. 46 (1974) 885-889.

7. Yang, S.S.: Determination of maleic hydrazide in tobacco by micellar liquid chromatography; J. Chroma togr. 595 (1992) 346-350.

8. Renaud, J.M., I. Keller and G. Vuillaume: Determination of maleic hydrazide residues in cured tobacco by gas chromatography; J. Chromatogr. 604 (1992) 243-246.

9. Kubilius, D.T. and R.J. Bushway: Determination of maleic hydrazide in potatoes and onions by fluorescence high-performance liquid chromatography; J. Liq. Chrom. Rel. Technol. 22 (1999) 593-601.

10. Vadukul, N.K.: Determination of maleic hydrazide in onions and potatoes using solid-phase extraction and anion-exchange high-performance liquid chromatography; Analyst 116 (1991) 1369-1371.

11. Dattilo, B.S., S. Gallo, G. Lionetti and S.G. Rossi: Determination of free and bound maleic hydrazide residues in tobacco by high-performance liquid chromatography; Beitr. Tabakforsch. Int. 16 (1994) 57-64.

12. Lewis, J.D., K.A. Barnes, K. Wilkinson, S.A. Thorpe, S.L. Reynolds, J.R. Startin: Extraction of maleic hydrazide from potato crisps and their determination using high-performance liquid chromatography with UV and atmospheric pressure chemical ionization mass spectrometric detection; J. Chromatogr. A 750 (1996) 391-396.

13. ISO 4876: Tobacco and tobacco products. Determination of maleic hydrazide residues; International Organization for Standardization, Geneva, 1980 (E).

14. Association of Official Analytical Chemists: Official methods of analysis, Vol. 1; edited by K. Elrich, Association of Official Analytical Chemists, Arlin gton, Virginia, 1990, pp 303-304.

15. Ihnat, M., R.S. Westerby and I. Hoffmann: Determination of maleic hydrazide residues in tobacco and vegetables; J. Assoc. Off. Anal. Chem. 56 (1973) 1164-1172.

16. Moldoveanu, S.C.: Pyrolysis GC/MS, Present and Future; J. Microcol. Separat. 13 (2001) 102-125.

\section{Address for correspondence:}

Serban Moldoveanu

Brown \& Williamson Tobacco Corp.

2600 Weaver Rd.

Macon GA, 31217

USA 